\title{
Present state and changes that occur within plant communities growing on the floating mat that surrounds the Moszne lake (Polesie National Park)
}

\author{
Stan obecny i zmiany zachodzące w zbiorowiskach \\ roślinnych występujących na splei otaczającej \\ jezioro Moszne (Poleski Park Narodowy)
}

*Mgr Anna Zagórowicz - Institute of Environmental Protection-National Research

Institute, Krucza 5/11d St., 00-548 Warsaw, e-mail: anna.zagorowicz@ios.gov.pl

Keywords: wetlands, transitional bog, long-term changes, Sørensen index, biodiversity, water condition changes Słowa kluczowe: mokradła, torfowiska przejściowe, długookresowe zmiany, wskaźnik Sørensena, różnorodność biologiczna, zmiany stosunków wodnych

\section{Abstract}

The first recordings of flora and vegetation in the surroundings of the Moszne lake (Polesie National Park) started from 1960. In 1980s the water conditions in this area changed and affected the organisms that lived there. The aim of this research was to recognize the present state and changes that occurred within flora and vegetation in the course of 18 years (1995-2013). In 2013, at the beginning of June, 34 phytosociological relevés were made on the floating mat that surrounds the Moszne lake in the same locations as they were done in 1995. The obtained data was collated with figures from the literature by comparing the frequency of plant species and plant communities, average plant species coverage and by calculating Sørensen indexes. The results showed that almost the same plant communities were identified in both terms of research. It was found that $35 \%$ of the plant species had disappeared after 18 years and that the biggest increase in percentage coverage was noted in case of Phragmites australis and Sphagnum fallax. Those findings show that it is very difficult and sometimes even impossible to reverse the negative influence of water condition change on bogs.

\section{๑) IOŚ-PIB}

\section{INTRODUCTION}

Wetlands are one of the priority habitats in countries of the European Union [Council Directive 92/43/EEC] because of their capacity to control flood, their ability to adapt to climate change, mitigation potential and biodiversity [Ramsar Convention Bureau 2001, Kadykalo Findlay 2016]. Due to changes in the environment and human economy (changes in water condition, fertility, $\mathrm{pH}$, overgrowth of abandoned open areas), they are at a risk of extinction [Hu et al. 2017]. Thus they need to be protected [Council Directive 92/43/EEC].

The first recordings of vegetation that occurred in the Moszne lake (Polesie National Park (PNP)) and in its surroundings were made by Fijałkowski [1960]. The Moszne lake was then a dystrophic forest reservoir surrounded by vast peat bogs, overgrown by plant communities characteristic of transitional

\section{Streszczenie}

Pierwsze dane dotyczące flory i roślinności występującej na splei otaczającej jezioro Moszne (Poleski Park Narodowy) pochodzą z 1960 r. W latach 80-tych nastąpiła zmiana warunków wodnych na tym terenie, co wpłynęło na związaną z tym obszarem roślinność. Celem podjętych badań było rozpoznanie obecnego stanu oraz zmian, jakie zaszły w obrębie szaty roślinnej na przestrzeni 18 lat (1995-2013). Na początku czerwca 2013 r. na splei otaczającej jezioro Moszne wykonano 34 zdjęcia fitosocjologiczne $w$ tych miejscach, w których były one wykonane w 1995 r. Następnie, uzyskane dane zestawiono z literaturą poprzez porównanie: występowania zbiorowisk roślinnych oraz gatunków roślin, obliczenie średniego procenta pokrywania oraz poprzez obliczenie wskaźnika Sørensena dla każdej grupy zdjęć fitosocjologicznych. Uzyskane wyniki pokazały, że: niemal te same zbiorowiska roślinne zostały zidentyfikowane w dwóch terminach badań, po 18 latach nie odnaleziono $35 \%$ gatunków z roku 1995, największy wzrost pokrycia odnotowano w przypadku Phragmites australis i Sphagnum fallax. Uzyskane wyniki wskazują, że bardzo trudno jest cofnąć (lub jest to niemożliwe) skutki zmian stosunków wodnych i ich wpływ na roślinność torfowiskową.

bog. In 1980s a lowering of the water level occurred, which also affected vegetation of the Moszne lake as evident by an increase in the area of shrub and tree encroachment [Chmielewski 2010]. Still the most valuable species survive, but plant communities have undergone changes, such as Characeae was replaced by Myriophyllum spicatum association, and the area covered by submerged macrophytes increased [Sender 2008]. Nowadays, waters of the Moszne lake are characterized as eutrophic, but they are still surrounded by a floating peat [Obidziński 2010]. The efforts undertaken by PNP to stop and reverse changes in ecological conditions are still in process. Thus there is a need to continue PNP's efforts to alleviate the effects of last century's actions, which changed the water conditions [Obidziński 2010]. The aim of the research on flora and vegetation of the Moszne 
lake was to investigate the current state and changes that occur within them over time.

\section{MATERIALS AND METHODS}

Research was conducted during the vegetation season at the beginning of June 2013 in the area that surrounds the Moszne lake. The maximum depth of the lake is $1 \mathrm{~m}$ and its catchment area occupies 17.5 ha [Sender 2008]. This area is overgrown by bog vegetation.

Thirty-four phytosociological relevés using the Brown-Blanquet method were made. Plant nomenclature was adopted following Mirek et al. [2002], moss nomenclature was adopted from Ochyra et al. [2003], Marchantiophyta nomenclature was taken from Szweykowski [2006] and syntaxonomic affiliation was made according to Matuszkiewicz [2002]. The locations of phytosociological relevés were selected in such a manner to match the relevés that were made in 1995. The next step was to combine this data with literature [Sugier i Popiołek 1998] by comparing the frequency of plant communities (Tab. 1) and plant species (Tab. 2), average plant species coverage in each year [Van der Maarel 2007]. The Braun-Blanquet scale was transformed into an average percentage coverage and then each species's average percentage coverage was summed in each year and divided by the total number of relevés (34).

\section{RESULTS AND DISCUSSION}

In both 1995 and in 2013, almost the same number of plant communities (12 and 11) and the same types of plant communities were identified on the floating mat that surrounds the Moszne lake. In 2013 two plant communities were not identified: Typhetum latifoliae and Vaccinio uliginosi-Pinetum. One was not present in 1995: Eriophoro vaginati-Sphagnetum recurvi.

Although almost the same plant associations were identified in both terms of research, only in 20 out of 34 research points the same plant associations were identified in both terms. In five cases, the plant community, which was different after 18 years, was Phragmitetum australis. In two other cases, SphagnoCaricetum rostratae was different in both terms.

In case of number of species identified in both terms of research, the differences are higher. In 1995 researchers identified 35\% more species than in 2013. There were 54 species that were recorded in both terms of research, of which 37 were present only in in 1995 and 6 identified only in 2013.

The following species reached higher percentage coverage in 1995 than in 2013: B. pubescens (17\%), T. palustris (11\%), M. trifoliate (9\%) and S. cinerea (6\%). In 2013 the species that covered more space of researched area are Sph. fallax (25\%), P. australis (7\%) and E. vaginatum (5\%) (Sugier i Popiołek 1998, Table 3). B. pubescens grows on moist and acidic surfaces and it avoids places where the soil is dry. T. palustris often forms a floating mat at the end of overgrowing of eutrophic lakes. $M$. trifoliate helps to form a floating mat. S. cinerea grows on peat in places that are usually flooded [Kłosowski, Kłosowski 2001]. $P$. australis is an expansive species that has massive appearance on bogs, leading to biodiversity loss [Próchnicki 2005, Próchnicki
Table 1. Plant communities identified on the floating mat that surrounds Moszne lake.

\begin{tabular}{|c|c|c|}
\hline Plant communities & 1995 & 2013 \\
\hline $\begin{array}{l}\text { Phragmitetum australis (Gams 1927) } \\
\text { Schmale } 1939\end{array}$ & + & + \\
\hline Typhetum latifoliae Soó 1927 & + & - \\
\hline $\begin{array}{l}\text { Sphagno-Caricetum rostratae (Steffen 1931) } \\
\text { em. Dierss, } 1982\end{array}$ & + & + \\
\hline $\begin{array}{c}\text { Caricetum appropinquatae (Koch 1926) } \\
\text { Soó } 1938\end{array}$ & + & + \\
\hline Caricetum limosae Br.-BI. 1921 & + & + \\
\hline Caricetum lasiocarpae Koch 1926 & + & + \\
\hline $\begin{array}{c}\text { Carici canescentis-Agrostietum caninae } \\
\text { R. Tx. } 1937\end{array}$ & + & + \\
\hline $\begin{array}{l}\text { Eriophoro vaginati-Sphagnetum recurvi Hueck } \\
1928 \text { pro ass. }\end{array}$ & - & + \\
\hline $\begin{array}{c}\text { Ledo-Sphagnetum magellanici Sukopp } \\
1959 \text { em. Neuhäusl } 1969\end{array}$ & + & + \\
\hline Molinietum caeruleae W.Koch 1926 & + & + \\
\hline $\begin{array}{l}\text { Salicetum pentandro-cinereae (Almq. 1929) } \\
\text { Pass. } 1961\end{array}$ & + & + \\
\hline forest community from Alnetea glutinosae & + & + \\
\hline Vaccinio uliginosi-Pinetum Kleist 1929 & + & - \\
\hline Total number of plant communities & 12 & 11 \\
\hline
\end{tabular}

2011]. E. vaginatum occurs on bogs and poor fens forming tussocks [Kłosowski, Kłosowski 2001].

In the moss layer, the most significant change is diminishing Sph. cuspidatum and growth in the percentage coverage of Sph. fallax. Both Sph. cuspidatum and Sph. fallax are species occurring in hollows of bogs, which are highly moist habitats [Kłosowki, Kłosowski 2001]. Sph. cuspidatum is one of the most aquatic species of Sphagnum and is normally found in very acidic habitats. It has poor competitive strengths and its coverage decreases when water table is low [Breeuwer et al. 2009, Robroek et al. 2007]. Sph. fallax, on the other hand, is tolerant of rather wide range of hydrological and chemical conditions. Its competitive strength is related to nitrogen and phosphorus availability [Temmink et al. 2017]. Gąbka and Lamentowicz [2008] report that Sph. fallax is an invasive species, which causes a decline of biodiversity of wetlands.

Changes in plant composition in wetlands are widely researched [Wentzell et al. 2016, Ma et al. 2017, Moges et al. 2017]. In many cases, changes in plant composition are conducted in relation to changes of some parameters in the environment: potential influence of climate change [Weltzin et al. 2003, Dieleman et al. 2014], changes in water chemistry [Leps 2004, Vicherova et al. 2015] after and during restoration [Hedberg et al. 2012, Kotowski et al. 2013, Van Diggelen et al. 2015] or trying to find the best way to sustain characteristic features of those habitats [Bergamini et al. 2009, Seer Schrautzer 2014]. Surveys involving plant composition changes taking time as the factor are rarer [Dyderski, Jagodziński 2016].

Researchers conducted in similar plant associations that formed on floating mat surrounding the Karzelek lake in a span of 13 years showed no differences in species composition nor in identified plant associations [Namura-Ochalska, Barszcz 2012]. After researching peat vegetation changes over the period of 14 
Table 2. Species identified on the floating mat that surrounds the Moszne lake.

\begin{tabular}{|c|c|c|}
\hline Species & 1995 & 2013 \\
\hline Agrostis canina L. & + & + \\
\hline Alnus glutinosa (L.) Gaertn. & + & + \\
\hline Andromeda polifolia L. & + & + \\
\hline Aulacomnium palustre (Hedw.)Schwaegr. & + & + \\
\hline Betula humilis Schrank & + & + \\
\hline Betula pubescens Ehrh. & + & + \\
\hline Carex appropinquata Schumach & + & + \\
\hline Calliergon stramineum (Brid.) Kindb. & + & + \\
\hline Calliergonella cuspidata (Hedw.) & + & + \\
\hline Carex canescens L. & + & + \\
\hline Carex chordorrhiza L. & + & + \\
\hline Carex echinata Murray & + & + \\
\hline Carex elata All. & + & + \\
\hline Carex lasiocarpa Ehrh. & + & + \\
\hline Carex limosa L. & + & + \\
\hline Carex nigra Reichard & + & + \\
\hline Carex panicea L. & + & + \\
\hline Carex pseudocyperus L. & + & + \\
\hline Peucedanum palustre (L.) Moench & + & + \\
\hline Phragmites australis (Cav.) Trin. ex Steud & + & + \\
\hline Pinus sylvestris L. & + & + \\
\hline Polytrichum strictum Menzies ex Brid. & + & + \\
\hline Quercus robur L. & + & + \\
\hline Ranunculus lingua L. & + & + \\
\hline Salix cinerea L. & + & + \\
\hline Salix lapponum L. & + & + \\
\hline Salix myrtilloides L. & + & + \\
\hline Salix pentandra L. & + & + \\
\hline $\begin{array}{l}\text { Salix repens L. ssp. rosmarinifolia (L.) Hartm. } \\
\text { Hartm. }\end{array}$ & + & + \\
\hline Scheuchzeria palustris $L$. & + & + \\
\hline Sphagnum fallax (Klinggr.) Klinggr. & + & + \\
\hline Sphagnum magellanicum Brid. & + & + \\
\hline Sphagnum palustre L. & + & + \\
\hline Sphagnum teres (Schimp.) Ångstr. & + & + \\
\hline Stellaria palustris Retz. & + & + \\
\hline Thelypteris palustris Schott & + & + \\
\hline Typha latifolia L. & + & + \\
\hline Vaccinium uliginosum L. & + & + \\
\hline Carex rostrata Stokes. & + & + \\
\hline Comarum palustre L. (L.) & + & + \\
\hline Drosera rotundifolia L. & + & + \\
\hline Dryopteris cristata (L.) A. Gray & + & + \\
\hline Equisetum fluviatile L. & + & + \\
\hline Eriophorum angustifolium Honck & + & + \\
\hline Eriophorum vaginatum $\mathrm{L}$. & + & + \\
\hline Frangula alnus Mill. & + & + \\
\hline Galium palustre L. & + & + \\
\hline Menyanthes trifoliata L. & + & + \\
\hline Molinia caerulea (L.) Moench & + & + \\
\hline Oxycoccus palustris Pers. & + & + \\
\hline Lysimachia thyrsiflora L. & + & + \\
\hline
\end{tabular}

\begin{tabular}{|c|c|c|}
\hline Species & 1995 & 2013 \\
\hline Lysimachia vulgaris $L$. & + & + \\
\hline Ledum palustre L. & + & + \\
\hline Dactylorhiza incarnata (L.) Soó & + & + \\
\hline Lophocolea heterophylla (Schrad.) Dumort. & + & - \\
\hline Lycopus europaeus L. & + & - \\
\hline Lythrum salicaria L. & + & - \\
\hline Mentha aquatica L. & + & - \\
\hline Agrostis stolonifera L. & + & - \\
\hline Bryum pseudotriquetrum Relh. & + & - \\
\hline $\begin{array}{l}\text { Calamagrostis canescens } \\
\text { (Weber) Roth }\end{array}$ & + & - \\
\hline Calla palustris L. & + & - \\
\hline Calliergon giganteum (Schimp.) Kindb. & + & - \\
\hline $\begin{array}{l}\text { Campylium polygamum (Schimp.) C.E.O. } \\
\text { Jensen }\end{array}$ & + & - \\
\hline Carex acuta L. & + & - \\
\hline Carex diandra Schrank & + & - \\
\hline Carex elongata L. & + & - \\
\hline Carex flava $\mathrm{L}$. & + & - \\
\hline Cephalozia connivens (Dicks.) Lindb. & + & - \\
\hline Cirsium palustre (L.) Scop. & + & - \\
\hline Drepanocladus aduncus (Hedw.) Warnst. & + & - \\
\hline $\begin{array}{l}\text { Limprichtia revolvens (Sw. ex anon.) Loeske in } \\
\text { Nitardy }\end{array}$ & + & - \\
\hline Eleocharis palustris (L.) Roem. et Schult. & + & - \\
\hline Epipactis palustris (L.) Crantz & + & - \\
\hline Hydrocharis morsus-ranae L. & + & - \\
\hline Juncus articulatus L. em. K. Richt. & + & - \\
\hline Nymphaea candida C. Presl & + & - \\
\hline Pedicularis palustris L. & + & - \\
\hline Pedicularis sceptrum-carolinum L. & + & - \\
\hline Potentilla erecta (L.) Raeusch. & + & - \\
\hline $\begin{array}{l}\text { Plagiothecium denticulatum Schimp. in Bruch, } \\
\text { Schimp. \& W. Gümbel }\end{array}$ & + & - \\
\hline $\begin{array}{c}\text { Plagiomnium elatum (Brunch \& Schimp.) T.J. } \\
\text { Kop. giomnium elatum }\end{array}$ & + & - \\
\hline Pohlia nutans (Hedw.) Lindb. & + & - \\
\hline Scorpidium scorpioides (Hedw.) Limpr. & + & - \\
\hline Scutellaria galericulata L. & + & - \\
\hline Solanum dulcamara L. & + & - \\
\hline Sphagnum cuspidatum Hoffm. & + & - \\
\hline Sphagnum nemoreum (Ehrh.) Hedw. & + & - \\
\hline Stratiotes aloides L. & + & - \\
\hline Triglohin palustre L. & + & - \\
\hline Utricularia vulgaris $\mathrm{L}$. & + & - \\
\hline Viola palustris $\mathrm{L}$. & + & - \\
\hline Acorus calamus L. & - & + \\
\hline Betula pendula Roth & - & + \\
\hline $\begin{array}{c}\text { Campylium stellatum (Hedw.) Lange \& C. Jens. } \\
\text { pylium stellatum (Hedw.) C. Jens. }\end{array}$ & - & + \\
\hline Galium uliginosum L. & - & + \\
\hline Juncus effusus L. & - & + \\
\hline Sphagnum rubellum Wilson & - & + \\
\hline Total number of species & 92 & 60 \\
\hline
\end{tabular}




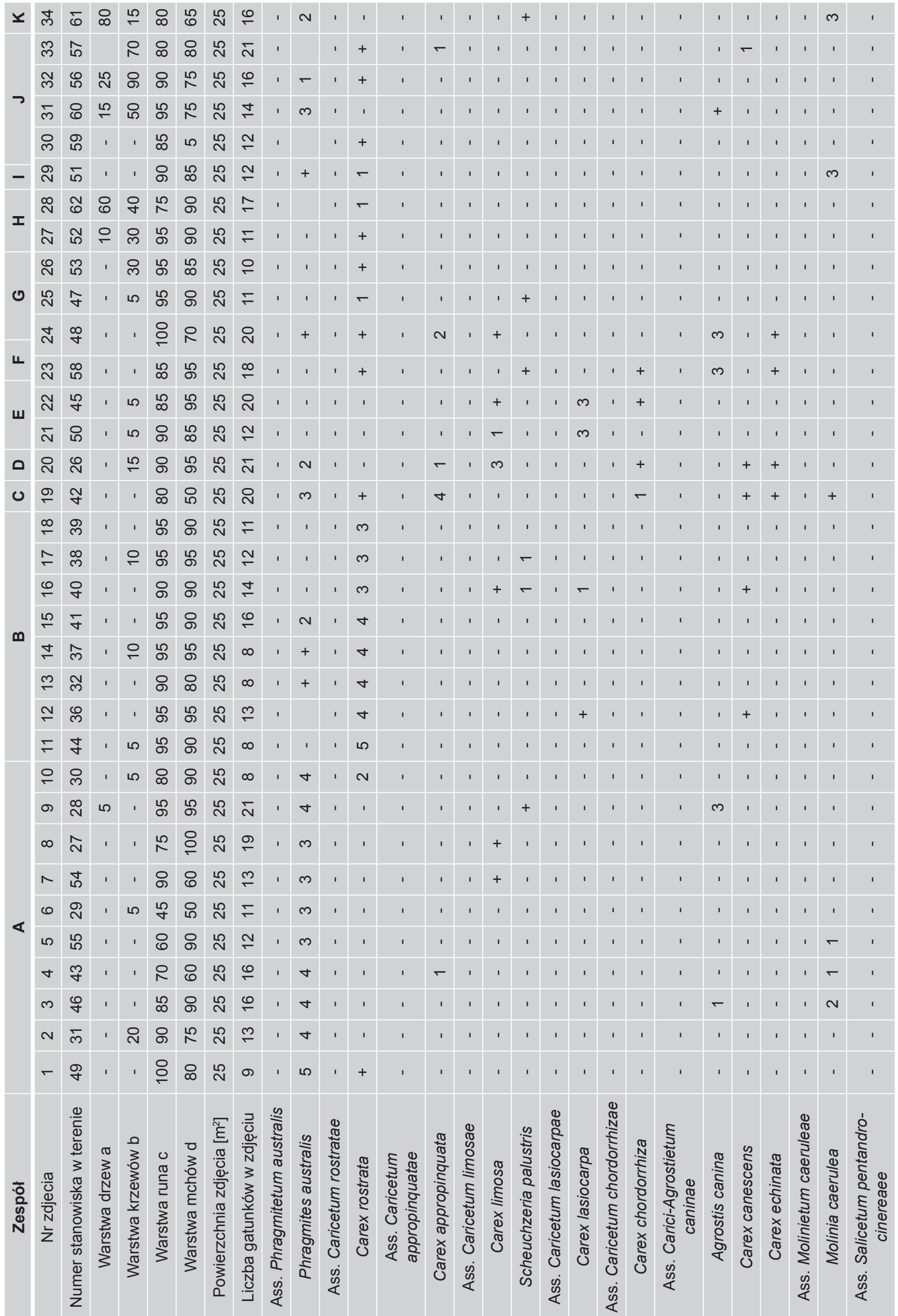




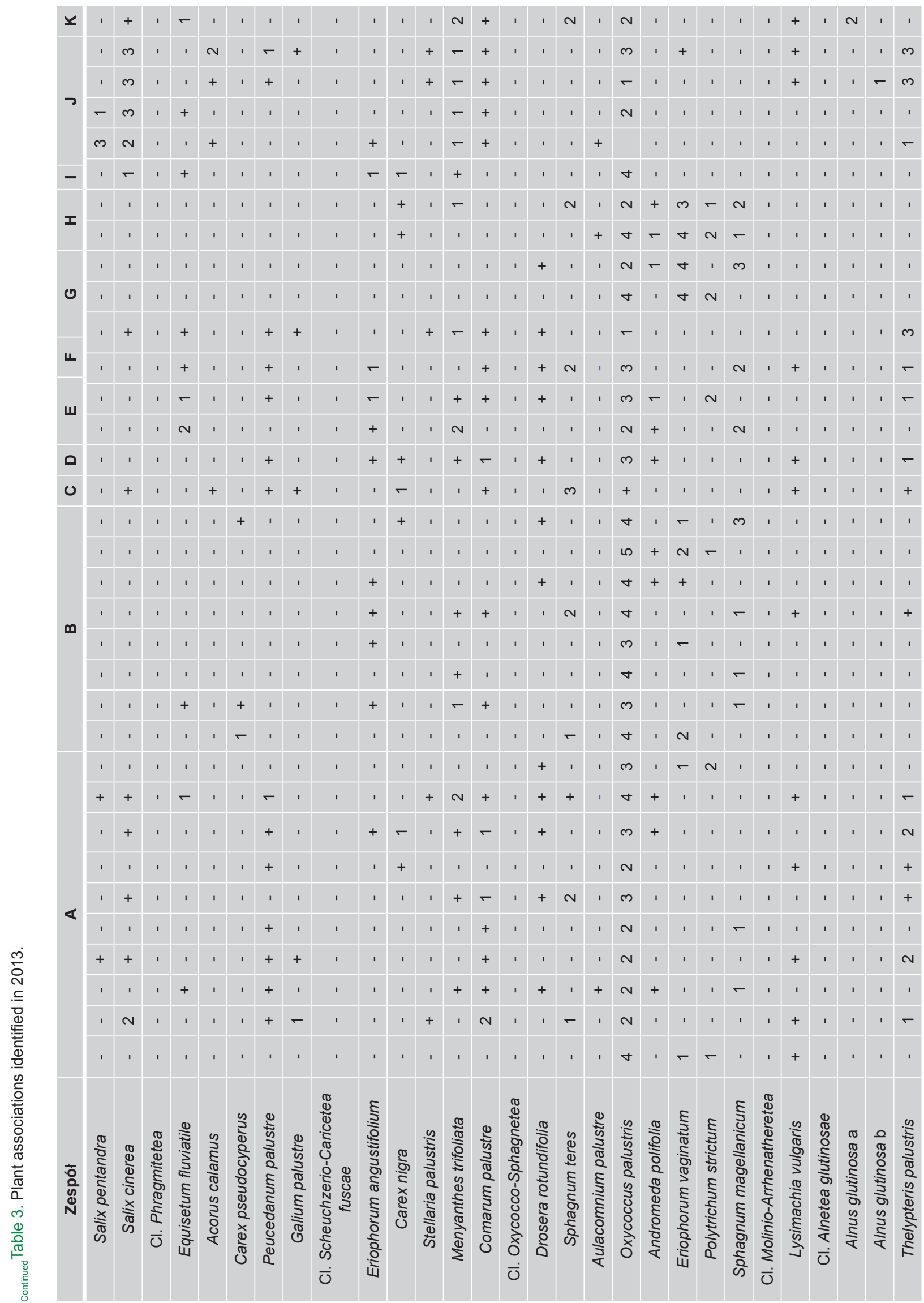




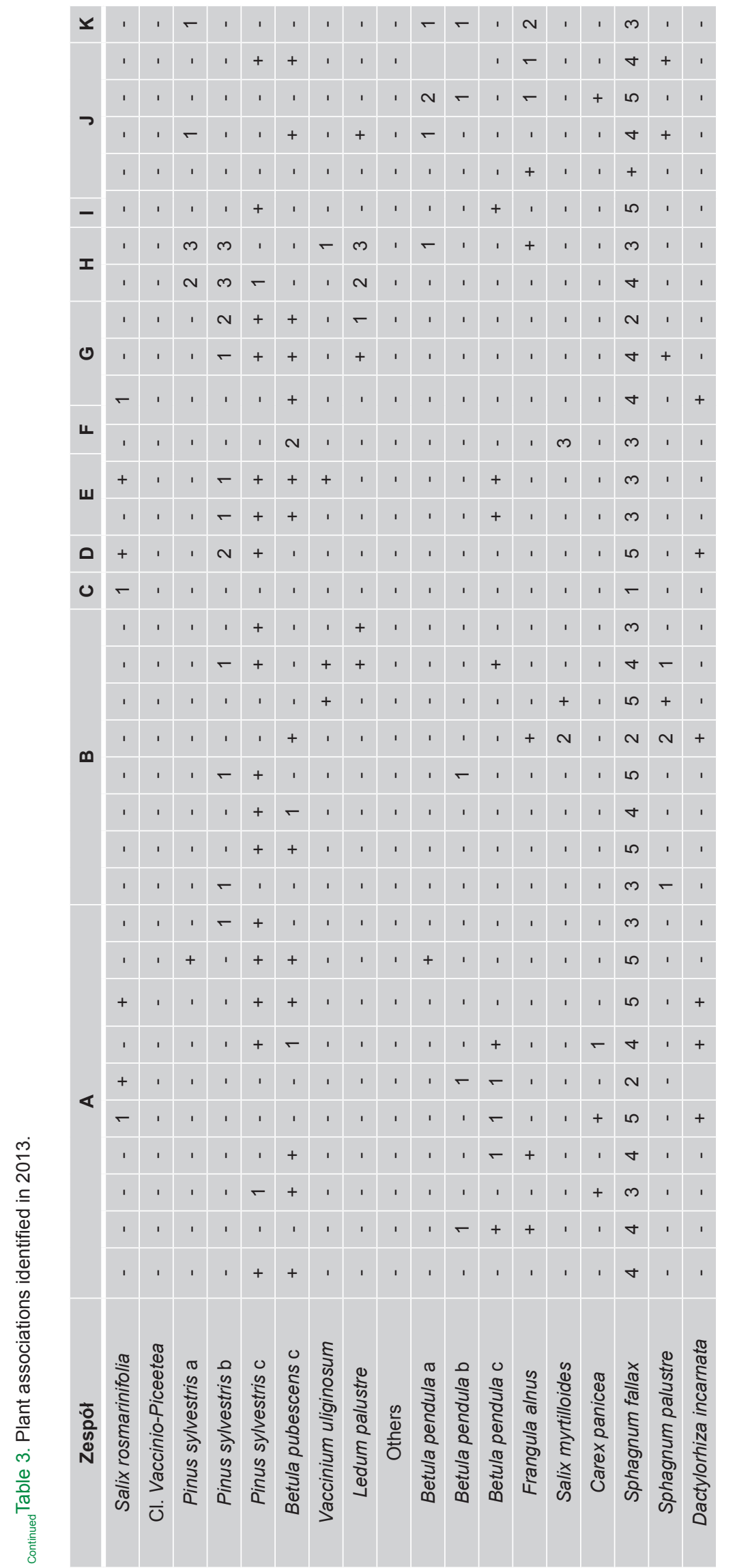

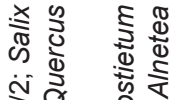

先 o

हิ

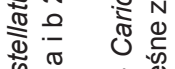

है

造

రิ

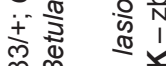

ह

ब.

हैं

ह

के

๑ొ

竞主

लె

\% क

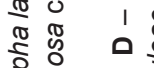

这

एक

वे

守落 ह

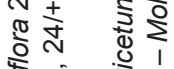

袋寺

.

पू

T⿱

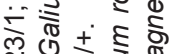

엉

ลำ

结象

今.

क्षे

ड़े⿺廴⿻肀二𠃋

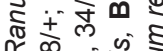

of $\infty$

索票

$+\frac{0}{2} \pi$

कo

$\frac{\pi}{\pi}, 0.0 \%$

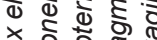

을

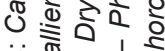

iิ

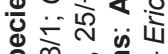

कิ

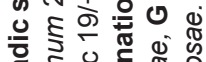

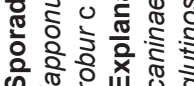


years, Dyderski and Jagodziński [2016] identified no significant shifts in plant species composition and the observed changes were not statistically significant. Sender [2008], who conducted research on long-term changes of macrophytes structure in the Moszne lake, noted a decrease of plant association variety as well as changes in their qualitative composition.

\section{CONCLUSIONS}

1. In the period of eighteen years, biodiversity of the studied area declined as evident by the fact that in 1995 there were $35 \%$ more species identified than in 2013.

\section{REFERENCES}

BERGAMINI A., PEINTINGER M., FAKHERAN S., MORADI H., SCHMID B., JOSHI J. 2009. Loss of habitats specialists despite conservation management in fen remnants 19952006. Perspect. Plant Ecol. 11(1): 65-79.

BREEUWER A., ROBROEK B.J.M., LIMPENS J., HEIJMANS M.M.P.D., SCHOUTEN M.G.C., BERENDSE F. 2009. Decreased summer water table depth affects peatland vegetation. Basic and Applied Ecology 10: 330-339.

CHMIELEWSKI T.J., CHMIELEWSKI S. 2010. Procesy zanikania ekosystemów jeziornych i torfowiskowych w rejonie Poleskiego Parku Narodowego od II połowy XX w. oraz perspektywy ich ochrony. Problemy Ekologii Krajobrazu, T. XXVI. 121-134.

Council Directive 92/43/EEC of 21 May 1992 on the conservation of natural habitats and of wild fauna and flora. Official Journal L 206, 22/07/1992.

DIELEMAN C.M., BRANFIREUN B.A., MCLAUGHLIN J.W., ZOELINDO. 2014. Climate change drives a shift in peatland ecosystem plan community: Implications foe ecosystem function and stability. Global Change Biol. Doi: 10.1111/gcb.12643.

DYDERSKI M.K., JAGODZIŃSKI A.M. 2016. Zmiany roślinności rezerwatu przyrody Mszar Bogdaniec. Leśne Prace Badawcze 77(2): 104-116.

FIJAŁKOWSKI D. 1960. Plant vegetation in lakes and adjacent peat bogs of Łęczna-Włodawa Lakeland. Ann. UMCS, sec. $B, X I V$.

GĄBKA M., LAMENTOWICZ M. 2008. Vegetation-environment relationships in peatlands dominated by Sphagnum fallax in Western Poland. Folia Geobot 43: 413-429.

HEDBERG P., KOTOWSKI W., SAETRE P., MALSON K., RYDIN H., SUNDBERG S. 2012. Vegetation recovery after multiplesite experimental fen restorations. Biol. Conserv. 147(1): 60-67.

HU S. et al. 2017. Global wetlands: Potential distribution, wetland loss, and status, Sci Total Environ (2017), http://dx.doi.org/ 10.1016/j.scitotenv.2017.02.001

KADYKALO A. N., FINDLAY C. S. 2016. The flow regulation services of wetlands. Ecosystem Services 20: 91-103.

KŁOSOWSKI S., KŁOSOWSKI G. 2001. Rośliny wodne bagienne. Multico Oficyna Wydawnicza. Warszawa. Ss. 336.

KOTOWSKI W., DZIERŻA P., CZERWIŃSKI M., KOZUB Ł., ŚNIEG S. 2013. Shrub removal facilities recovery of wetland species In a rewetted fen. J. Nat. Conserv. 21(5): 294-308.
2. In 2013 growth in percentage coverage of $P$. australis, Phragmitetum australis and Sph. fallax is identified, which could be affect the changes of water conditions and cause further biodiversity decline of the area that surrounds the Moszne lake.

3. Although Polesie National Park since its foundation is continuously working on an improvement of water condition of its area after changes had occurred in the past, the effects of these changes are still not reversed. Every change in water condition that affects bogs require a lot of time and effort to be reversed or it can be even impossible.

LEPS J. 2004. Nutrient limitation and nutrient-driven shifts in plant species composition in a species-rich fen meadow. J. Veg. Sci. 15(3): 389-396.

MA M., BASKIN C.C., YU K., MA Z., DU G. 2017 Wetland dryling indirectly influences plant community and seed bank diversity through soil pH. Ecol. Indic. 80: 186-195.

MATUSZKIEWICZ W. 2002. Przewodnik do oznaczania zbiorowisk roślinnych Polski. (Guidebook for identification of plant communities In Poland). Warszawa, PWN: 1-537.

MIREK Z., PIĘKOŚ-MIRKOWA H., ZAJĄC A., ZAJĄC M. 2002. Flowering plants and pteridophytes of Poland - a checklist. Vol. 1. Ed. Z. Mirek. Kraków, Inst. Bot. im. W. Szafera PAN: 1-442.

MOGES A., BEYENE A., AMBELU A., MERETA S.T., TRIEST L., KELBESSA E. 2017. Plant species composition and diversity in wetlands under forest, agriculture and urban land uses. Aquatic Botany 138: 9-15.

NAMURA-OCHALSKA A., BARSZCZ A. 2012. Ocena zmian flory i roślinności $w$ kolejnych strefach zarastania jeziora "Karzełek". Fragm. Florist. Geobot. Polon. 19(2): 475-483.

OBIDZIŃSKI A. (red.). 2010. Z Mazowsza na Polesie i Wileńszczyznę. Zróżnicowanie i ochrona szaty roślinnej pogranicza Europy Środkowej i Północno-Wschodniej. Monografia sesji terenowych LV Zjazdu Polskiego Towarzystwa Botanicznego Planta in vivo, in vitro et in silico. Warszawa, 6-12 września 2010.

OCHYRA R., ŻARNOWIEC J., BEDNAREK-OCHYRA H. 2003. Census catalogue of Polish mosses. Institute of Botany, Polish Academy of Sciences, Kraków: 1-372.

PRÓCHNICKI P. 2005. The expansion of common Reed (Phragmites australis (Cav.) Trin. ex Steud.) in the anastomosing River Valley after cessation of agriculture use (Narew River Valley, NE Poland). Pol. J. Ecol. 53(3): 353-364.

PRÓCHNICKI P. 2011. Wykorzystanie wczesnowiosennych zobrazowań satelity LANDSAT-ETM w monitoringu zbiorowisk z udziałem trzciny pospolitej. Woda-Środowisko-Obszary wiejskie t. 11 z. 2(34): 125-133.

RAMSAR CONVENTION BUREAU, 2001 Wetlands values and functions. Ramsar Convention Bureau. Gland, Switzerland

ROBROEK B.J.M., LIMPENS J., BREEUWER A., SCHOUTEN M.G.C. 2007. Effect of water level and temperature on performance of four Sphagnum mosses. Plant Ecol 190: 97-107. 
SEER F.K., SCHRAUTZER J. 2014. Status, future prospects, and management recommendations for alkaline fens in a agricultural landscape: A comprehensive survey. J. Nat. Conserv. 22 (4): 358-368

SENDER J. 2008. Long term changes of macrophytes structure in the lake Moszne (Poleski National Park). Teka Kom. Ochr. Kszt. Środ. Przyr.5: 154-163.

SUGIER P., POPIOŁEK Z., 1998. Water and riparian vegetation of Lake Moszne in the Poleski National Park. Ann. UMCS sec. C, LIII, 185-201.

SZWEYKOWSKI J. 2006, An annotated checklist of Polish liverworts and hornworts. W. Szafer Institute of Botany, Polish Academy of Sciences, Kraków, 7-82.

TEMMINK R.J.M., FRITZ CH., VAN DIJK G., HENSGENS G., LAMERS L.P.M., KREBS M., GAUDIG G., JOOSTEN H., 2017. Sphagnum farming in a eutrophic world: The importance of optimal nutrient stoichiometry. Ecological Engineering 98 : 196-205

VAN DER MAAREL E. 2007. Transformation of cover-abundance values for appropriate numerical treatement - Alternatives to the proposals by Podani. J. Veg. Sci.18: 767-770.
VAN DIGGELEN J.M.H., BENSE I.H.M., BROUWER E., LIMPENS J., VAN SCHIE J.M.M., SMOLDERS A.J.P., LAMERS L.P.M. 2015. Restoration of acidified and eutrophied rich fens: Long-term effects of traditional management and experimental liming. Ecol. Eng. 75: 208-216.

VICHEROVA E., HAJEK M., HAJEK T. 2015. Calcium intolerance of fen mosses: Physiological evidence, effectcs of nutrient availability and successional drivers. Perspect. Plant Ecol. 17(5): 347-359.

WELTZIN J.F., BRIDGHAM S.D., PASTOR J., CHEN J., HARTH C. 2003. Potential effects of warming and drying on peatland plant community composition. Global Change Biol. 9: 141151.

WENTZELL B.M., BOYLEN CH.W., NIERZWICKI-BAUER S.A. 2016. Wetland ecosystem comparison using a suite of plant assessment measures. Ecol. Indic. 67: 283-291. 